Gut, 1976, 17, 551-560

\title{
Gastric morphology and serum gastrin levels in pernicious anaemia ${ }^{1}$
}

\author{
K. J. LEWIN 2 , F. DOWLING, JILL P. WRIGHT, AND K. B. TAYLOR \\ From the Departments of Pathology and Medicine, Stanford University Medical School, California, U.S.A.
}

SUMMARY Mucosal biopsies from multiple sites in the stomachs of 21 patients with pernicious anaemia have been examined. The histological changes almost always involved the entire gastric mucosa, including that of the pyloric antrum. Metaplastic changes were almost universal and consisted of intestinal metaplasia in the body and antrum and pyloric metaplasia in the body. The severity of the pyloric metaplasia was such as to make the distinction between body and antrum on biopsy impossible. No relationship was found between serum gastrin activity and the histological appearances of the gastric antrum or body.

The past 25 years have witnessed the introduction of techniques whose application has contributed substantially to the investigation of the nature of chronic gastritis. Peroral suction biopsy (Wood et al., 1949; Joske et al., 1955) of the body and fundus of the stomach has provided a solid histological foundation which, in conjunction with measurements of gastric secretion of acid (Bock et al., 1963) and intrinsic factor and the detection of gastric antibodies (te Velde et al., 1966; Fisher et al., 1967), has considerably extended our knowledge of the pathophysiology of the body of the stomach.

In contrast, the structure and function of the gastric antrum was until recently little studied. The introduction of the fibreoptic gastroscope made possible multiple biopsying of the gastric mucosa from well-defined sites in the body and pyloric antrum (Seifert and Knoll, 1968; Konturek and Urban, 1969; Ottenjann et al., 1969a, b) and the development of radioimmunoassay of gastrin activity (Wood et al., 1949) provided a test of antral secretory function (Strickland et al., 1971).

The aim of this study was to investigate the range of gastric mucosal appearances in chronic atrophic gastritis, of the type associated with Addisonian pernicious anaemia (PA) and consider it in relation to changes of secretory functions of both gastric body and pyloric antrum and the presence of circulating gastric antibodies.

${ }^{1}$ This investigation was supported by a General Research Support Grant RR-5353-12 (Dr Lewin) and USPHS AM 06971 and the Veterans Administration (Dr Taylor).

${ }^{2}$ Address for reprint requests: Dr Klaus Lewin, Department of Pathology, Room L235, Stanford University Medical School, Stanford, California 94305, U.S.A.

Received for publication 12 March 1976

\section{Methods}

\section{PATIENTS}

Eighteen patients (14 women and four men) referred to our clinic at Stanford University Medical Center with established or suspected PA were studied. Diagnosis was established by failure to secrete detectable acid in response to a maximal dose of gastric stimulant (betazole $1.7 \mathrm{mg} / \mathrm{kg}$ body weight) and urinary excretion of less than $10 \%$ of a $0.5 \mu \mathrm{g}$ oral dose of ${ }^{57} \mathrm{Co} \mathrm{B}_{12}$ in a standard Schilling test, which was corrected with added gastric intrinsic factor. Supporting evidence was low serum vitamin $\mathbf{B}_{12}$ activity, low or absent gastric intrinsic factor secretion, and the presence of circulating gastric antibodies.

In addition, studies are included of three patients who were referred for suspected PA but in whom the above criteria were not completely fulfilled (Table 1).

\section{TECHNIQUE}

Serum parietal canalicular antibody $(\mathrm{PCA})^{3}$ was detected by the immunofluorescence technique of Taylor et al. (1962), and intrinsic factor (IF) antibodies by the guinea-pig ileal homogenate technique of Ashworth et al. (1967).

\section{Estimation of serum gastrin activity}

This was done by a modification of the radioimmunoassay method of Yalow and Berson (1970), in which polyethylene glycol instead of resin was used

\footnotetext{
${ }^{3}$ This seems a better term than parietal cell antibody in light of the demonstration by Hoedemaker and Ito (1970) of the nature of the reactive antigen.
} 
Table 1 Gastric antibodies and gastrin concentrations in sera of 21 patients with pernicious anaemia

\begin{tabular}{|c|c|c|c|c|c|}
\hline \multirow[t]{2}{*}{ Patient no. } & \multirow[t]{2}{*}{$A g e(y r)$} & \multirow[t]{2}{*}{ Sex } & \multicolumn{2}{|l|}{ Antibodies } & \multirow{2}{*}{$\begin{array}{l}\text { Serum gastrin } \\
(\mathrm{pg} / \mathrm{ml})\end{array}$} \\
\hline & & & $\begin{array}{l}\text { Parietal canalicular } \\
\text { antibody }\end{array}$ & $\begin{array}{l}\text { Intrinsic factor } \\
\text { (blocking) }\end{array}$ & \\
\hline 1 & 33 & $\mathbf{F}$ & + & + & 730 \\
\hline 2 & 66 & $\mathbf{F}$ & + & + & 1600 \\
\hline 3 & 64 & $\mathbf{M}$ & + & + & 120 \\
\hline 4 & 35 & $\mathbf{F}$ & + & + & 1889 \\
\hline 5 & 43 & $\mathbf{M}$ & + & + & 930 \\
\hline 6 & 28 & $\mathbf{F}$ & + & + & 420 \\
\hline 7 & 39 & $\mathbf{F}$ & + & + & 4000 \\
\hline 8 & 56 & $\mathbf{M}$ & - & - & 2080 \\
\hline 9 & 44 & $\mathbf{F}$ & + & - & 1480 \\
\hline 10 & 51 & $\mathbf{F}$ & + & - & 890 \\
\hline 11 & 70 & $\mathbf{F}$ & + & + & 240 \\
\hline 12 & 54 & $\mathbf{M}$ & + & + & 150 \\
\hline 13 & 74 & $\mathbf{F}$ & + & + & 190 \\
\hline 14 & 75 & $\mathbf{F}$ & + & + & 120 \\
\hline 15 & 54 & $\mathbf{F}$ & + & - & 400 \\
\hline 16 & 33 & $\mathbf{F}$ & + & + & 100 \\
\hline $17^{*}$ & 64 & $\mathbf{F}$ & + & + & 1810 \\
\hline 18 & 52 & $\mathbf{F}$ & + & + & 190 \\
\hline $19 \dagger$ & 61 & $\mathbf{F}$ & + & + & 1500 \\
\hline $20 \dagger$ & 51 & $\mathbf{F}$ & + & + & 110 \\
\hline $21 \dagger$ & 47 & $\mathbf{F}$ & + & + & 1990 \\
\hline
\end{tabular}

* Patient on steroids, normal Schilling test.

†Patients with latent PA (chronic atrophic gastritis, circulating gastric antibodies. Schilling tests in the low normal range).

to separate antibody-bound from antibody-free gastrin.

Antisera to crude porcine gastrin conjugated with bovine-serum albumin by the method of Yip and Jordan (1970), were obtained by immunization of Hartley-strain female guinea-pigs, according to a schedule of multiple subcutaneous injections at one month intervals. These antisera have been characterised (Rosenquist and Holmquist, 1974). They recognise the C-terminal tetrapeptide of synthetic human gastrin I (ICI) and display increasing binding over the tetra-octapeptide range (Rosenquist and Holmquist, 1974).

Synthetic human gastrin I (ICI Batch No. 630/20), labelled with ${ }^{125}$ iodine by the modified chloramine-T method of Hunter and Greenwood (1962), was used as the trace. Antisera concentrations were selected to give a maximal binding capacity of approximately $30 \%$. All serum samples were tested in triplicate, with duplicate controls (no antibody added). Separation of antibody-bound to antibody-free gastrin was effected by adding an equal volume of polyethylene glycol 6000 (PEG), 30\% wt/wt solution in distilled water, to the reaction mixture. Standard inhibition curves were established for each assay.

Radioactivity in the PEG precipitates was estimated in an automatic gamma counter (Nuclear Chicago Model 1085, Serial 130). The counts were transmitted by teletype to a computer and the computed data expressed as means \pm 1 standard deviation, a standard curve being obtained from the same assay. In 100 subjects without gastrointestinal disease, the mean serum gastrin was 97 SD $46.7 \mathrm{pg}$ / $\mathrm{ml}$, range 4-197 $\mathrm{pg} / \mathrm{ml}$. In 12 such sera repeatestimations gave 48 SD $17 \cdot 4$ and 65 SD $6.4 \mathrm{pg} / \mathrm{ml}$ respectively.

\section{Gastric biopsies}

Before biopsy, informed consent was obtained from all patients after the nature of the gastroscopic biopsy procedure had been fully explained.

All gastric biopsies were obtained using the American Cystoscope, Inc. fibreoptic gastroscope and crocodile forceps. In one patient samples were taken by surgical biopsy during cholecystectomy.

Specimens were taken in all patients from the body of the stomach and pyloric antrum. Some biopsies from the pyloric antrum were inadequate for proper examination and were excluded from the study. Multiple biopsies of the body were performed in 12 patients, the sites being designated high-, mid-, and low-body areas. In three patients, biopsies were taken from proximal and distal antrum. Repeat studies were done in five patients in whom serial gastroscopic examination was indicated for clinical reasons.

Specimens were immediately mounted on gel foam or cardboard to prevent curling and loss of orientation and fixed in $10 \%$ buffered formol-saline. They were subsequently processed for light microscopy in the usual fashion, care being taken to orientate them properly before embedding. Biopsies were 
finally checked by examining a methylene bluestained preliminary section. Serial 5 micron sections were then cut at right angles to the surface and stained with haematoxylin and eosin ( $\mathrm{H}$ and $\mathrm{E})$ and phosphotungstic acid haematoxylin (PTAH) to display the parietal cells. Selected sections were stained with periodic acid Schiff (PAS) and elastic Van Gieson (EVG) reagents. The sections were coded and classified by light microscopy independently by two observers.

Biopsies from both body and pyloric antrum were graded according to mucosal thickness, atrophy of glands and specialized cells, degree and type of inflammation, extent and type of metaplasia and endocrine cell content. Each parameter was graded in severity from + to ++++ .

Atrophy was indicated by shrinkage of glands and loss of parietal and chief cells. $1+$ indicated minimal shrinkage of glands and a mild decrease in specialized cells: $2+$ a moderate decrease; $3+$ a severe decrease of specialized cells with small residual glands; $4+$ similar to $3+$ but with complete absence of specialized cells. Both intestinal and pyloric metaplasia were assessed according to extent of involvement of the biopsy; $4+$ indicating complete replacement; $1+$ a minimal focus. The inflammatory infiltrate was graded from $1+$ to $4+$ according to the severity of inflammatory infiltrate. The endocrine cells were identified by their site and readily recognizable morphological features, including perinuclear haloes. Special staining to subclassify these cells was not performed.

\section{Results}

The incidence of gastric antibodies in the group of PA patients studied fell within the expected range. The serum of only one subject was negative for PCA and IF blocking antibody was present in $80 \%$ (Table 1).

The fasting serum gastrin activities ranged from $100-4000 \mathrm{pg} / \mathrm{ml}$ (Table 1). There was no correlation between age and serum gastrin levels. Patients without detectable IF antibodies were only four in number and displayed serum gastrin of 400,800 , 1480 , and $2080 \mathrm{pg} / \mathrm{ml}$. These numbers, though small, do not suggest any trend.

In order to assess the severity of the inflammatory infiltrate we first examined the gastric mucosa of histologically normal controls. These specimens are hard to come by since most gastric biopsies and operation specimens are associated with either primary or secondary inflammation. Necropsy specimens are usually severely autolyzed unless removed and fixed within a few hours of death. Five gastric specimens were obtained, which were suitable as

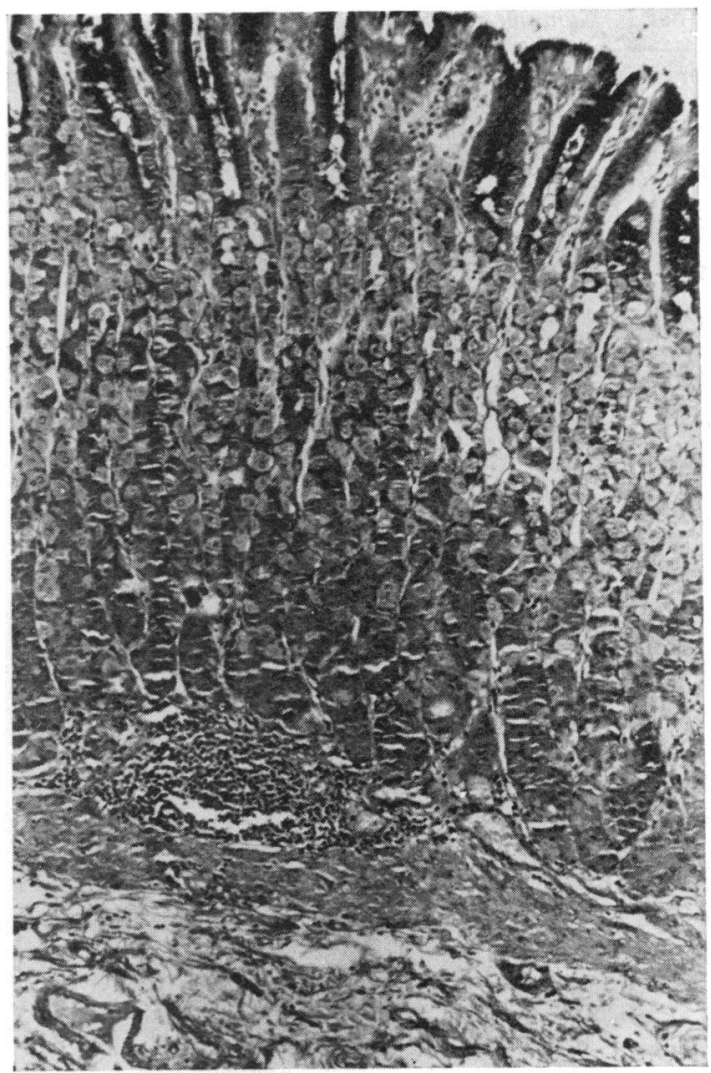

Fig. 1 Low power photomicrograph of normal gastric mucosa from body, showing the straight tubular glands and the foveolae (gland pits) which occupy about onethird the depth of the mucosa. Note the scant inflammatory infiltrate found mainly in the lamina propria around the foveolae and lymphoid follicle adjacent to muscularis mucosa. PAS, $\times 100$.

controls. Two were from necropsy cases without gastrointestinal involvement and were obtained within a few hours of death. Three were surgical specimens and consisted of an oesophagogastrectomy for carcinoma of the oesophagus and two partial gastrectomies for duodenal ulcer disease.

In biopsies from the body (Fig. 1) the inflammatory infiltrate was sparse, consisting of plasma cells, lymphocytes, and an occasional eosinophil. These cells were principally found subepithelially around the foveoli, with an occasional inflammatory cell adjacent to the muscularis mucosae.

In the normal pyloric antrum (Fig. 2) there was a more variable inflammatory infiltrate ranging from minimal, as in the body, to a mild degree designated $1+$ for purposes of comparison with biopsies from the gastric body. Occasional lymphoid follicles were 
Table 2 Summary of pathological findings in 21 patients with atrophic gastritis

\begin{tabular}{|c|c|c|c|c|c|c|c|c|c|}
\hline \multirow[t]{2}{*}{ Patient no. } & \multirow[t]{2}{*}{$\operatorname{Age}(y r)$} & \multirow[t]{2}{*}{ Sex } & \multirow[t]{2}{*}{ Site } & \multirow{2}{*}{$\begin{array}{l}\text { Inflamma- } \\
\text { tion }\end{array}$} & \multirow{2}{*}{$\begin{array}{l}\text { Glandular } \\
\text { atrophy }\end{array}$} & \multicolumn{2}{|l|}{ Metaplasia } & \multirow{2}{*}{$\begin{array}{l}\text { Endocrine } \\
\text { cell hyper- } \\
\text { plasia }\end{array}$} & \multirow[t]{2}{*}{ Biopsy* } \\
\hline & & & & & & Pyloric & Intestinal & & \\
\hline \multirow[t]{2}{*}{1} & 33 & $\mathbf{F}$ & Antrum & + & + & & 0 & 0 & \\
\hline & & & body & ++ & ++ & $+t+$ & 0 & 0 & \\
\hline \multirow[t]{2}{*}{2} & 66 & $\mathbf{F}$ & Antrum & $++t$ & $++t$ & & 0 & 0 & \\
\hline & & & body & $+t+$ & +++ & $\mathbf{0}$ & +++ & $\mathbf{0}$ & \\
\hline 3 & 64 & $\mathbf{M}$ & Antrum & ++ & $+t+$ & $++t$ & & & \\
\hline \multirow[t]{2}{*}{4} & 35 & $\mathbf{F}$ & Antrum & $\begin{array}{l}++ \\
+\end{array}$ & $\begin{array}{l}+++t \\
+++\end{array}$ & +++ & $0^{+}$ & $0^{+}$ & $\mathbf{M}$ \\
\hline & 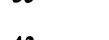 & & body & ++ & +++ & $\mathbf{0}$ & +++ & 0 & \\
\hline \multirow[t]{2}{*}{5} & 43 & $\mathbf{M}$ & Antrum & ++ & +++ & & 0 & 0 & \\
\hline & & & body & ++ & +++ & $++t$ & 0 & 0 & \\
\hline \multirow[t]{2}{*}{6} & 28 & $\mathbf{F}$ & Antrum & ++ & $++t$ & & 0 & 0 & \\
\hline & & & body & ++ & +++ & $++t$ & 0 & $\div$ & \\
\hline \multirow[t]{2}{*}{7} & 39 & $\mathbf{F}$ & Antrum & ++ & +++ & & 0 & 0 & M, RB \\
\hline & 56 & $\mathbf{M}$ & $\begin{array}{l}\text { body } \\
\text { Antrum }\end{array}$ & $\begin{array}{l}+++ \\
+\end{array}$ & $\begin{array}{l}+++ \\
+\end{array}$ & ++ & $0^{++}$ & +++ & M, RB \\
\hline 8 & 50 & 101 & body & +++++ & $+++t$ & +++ & $+t$ & +1 & \\
\hline 9 & 44 & $\mathbf{F}$ & Antrum & & & , & & & \\
\hline \multirow[t]{2}{*}{10} & 51 & $\mathbf{F}$ & $\begin{array}{l}\text { body } \\
\text { Antrum }\end{array}$ & +++ & +++ & +++ & +++ & + & M, RB \\
\hline & 70 & $\mathbf{F}$ & $\begin{array}{l}\text { body } \\
\text { Antrum }\end{array}$ & $\begin{array}{l}+++++t \\
++\end{array}$ & $\begin{array}{l}++ \\
+\end{array}$ & ++ & ${ }_{0}^{++}$ & 0 & $\mathbf{M}$ \\
\hline 11 & 70 & $\boldsymbol{F}$ & body & $+++t$ & ++ & ++ & $++t$ & $+t+$ & $\mathbf{M}$ \\
\hline 12 & 54 & $\mathbf{M}$ & Antrum & $\begin{array}{l}++ \\
+t\end{array}$ & + & & & 0 & \\
\hline \multirow[t]{2}{*}{13} & 74 & $\mathbf{F}$ & Antrum & ++ & +++ & 0 & ++ & 0 & \\
\hline & & & body & ++ & +++ & + & +++ & 0 & M \\
\hline \multirow[t]{2}{*}{14} & 75 & $\mathbf{F}$ & Antrum & & $0++$ & & 0 & $\mathbf{0}$ & \\
\hline & & & body & ++ & $++t$ & +++ & + & 0 & M, RB \\
\hline 15 & 54 & $\mathbf{F}$ & Antrum & + & ++ & & 0 & 0 & \\
\hline \multirow{2}{*}{16} & 33 & $\mathbf{F}$ & body & +++ & ++++ & ++ & 0 & 0 & \\
\hline & & & $\begin{array}{l}\text { Antrum } \\
\text { body }\end{array}$ & $\stackrel{+}{+}+++++$ & 0 & $\begin{array}{l}0 \\
++t\end{array}$ & 0 & 0 & $\mathbf{M}$ \\
\hline \multirow[t]{2}{*}{17} & 64 & $\mathbf{F}$ & Antrum & $T T T T T T$ & T T T T & $T+t$ & + & $T$ & $1 \mathrm{~N}$ \\
\hline & & & body & ++ & $++t$ & 0 & + & 0 & $\mathbf{M}$ \\
\hline 18 & 51 & $\mathbf{F}$ & Antrum & + & +++ & & 0 & 0 & RB \\
\hline & & & body & +++ & ++++ & ++ & 0 & $\mathbf{0}$ & $\mathbf{M}, \mathbf{R B}$ \\
\hline 19 & 61 & $\mathbf{F}$ & Antrum & ++ & + & & 0 & + & \\
\hline 20 & 51 & $F$ & $\begin{array}{l}\text { body } \\
\text { Antrum }\end{array}$ & ++ & +++ & + & + & 0 & $\mathbf{M}$ \\
\hline & & & body & + & + & $\mathbf{0}$ & 0 & 0 & \\
\hline 21 & 47 & F & Antrum & + & 0 & 0 & 0 & 0 & $\mathbf{M}$ \\
\hline & & & body & ++ & ++++ & $+++t$ & +++ & +++ & $\mathbf{M}$ \\
\hline
\end{tabular}

*M: multiple biopsies.

RB: repeat biopsies.

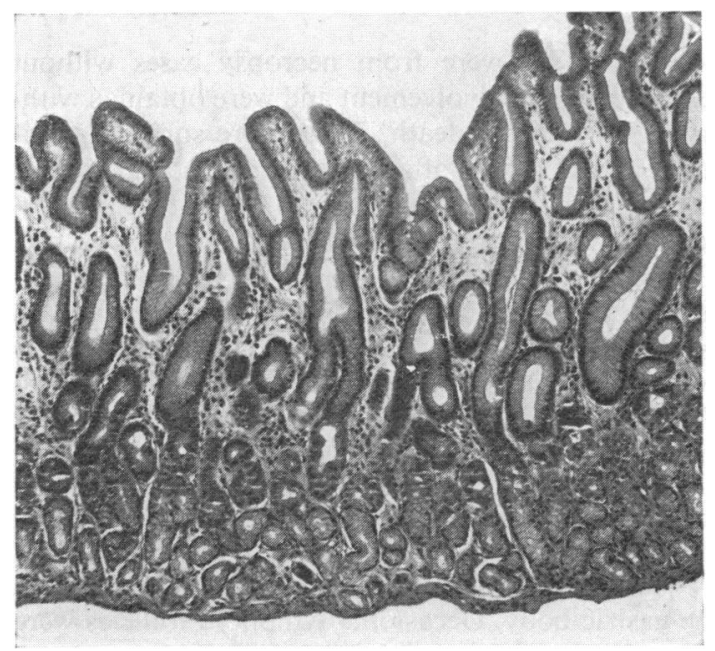

seen above the muscularis mucosae both in the body and pyloric antrum.

The histological findings in the gastric specimens are summarized in Table 2. The surface epithelium was lined by columnar cells, and occasionally small papillary projections were seen around gland orifices. These features were not significantly different from the normal. However, there were occasional small foci where the columnar epithelium was replaced by low cuboidal epithelium.

The intensity of the inflammation was greater in the body than the pyloric antrum and ranged from

Fig. 2 Low power photomicrograph of normal gastric mucosa from pyloric antrum, showing coiled mucous glands and the foveolae which occupy about one-half the depth of the mucosa. Note the mild chronic inflammatory infiltrate in the lamina propria. $H$ and $E, \times 65$. 


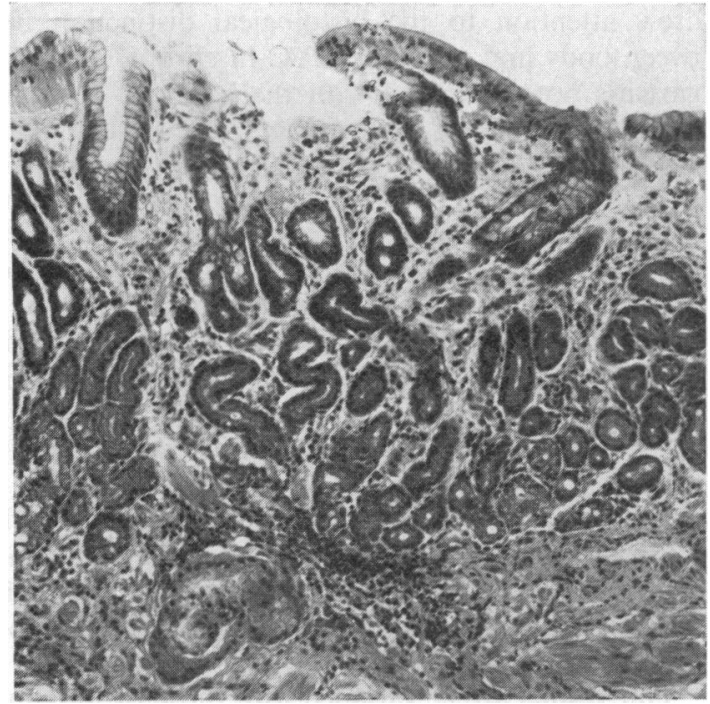

Fig. 3 Gastric mucosa from body in chronic atrophic gastritis showing severe glandular atrophy and chronic inflammation of moderate severity. There is complete loss of specialized cells and replacement by undifferentiated columnar cells. $H$ and $E, \times 80$.

mild to very severe, but was moderately severe in most cases (Figs. 3, 4). The inflammatory cells consisted primarily of plasma cells and lymphocytes with a sprinkling of eosinophils in almost all of the cases. In four biopsies the number of eosinophils was more prominent. Neutrophils were rare.

Atrophy (Figs. 3, 4, 5) of the gastric fundus was very severe in most cases, although sometimes the mucosal thickness was modified by metaplastic change producing what appeared to be an increase in gland size. In contrast with the fundus, atrophy of the pyloric antrum was usually mild-to-moderate and absent in two cases.

Metaplastic changes were almost universal in the gastric fundus and consisted of two types of epithelium, small intestinal and pyloric (Figs. 5, 6). Small intestinal-type epithelium was usually manifested by columnar absorptive cells, goblet cells, and Paneth cells. In five cases intestinal villi were present. Pyloric metaplasia was seen in 16 cases and was sometimes indistinguishable from pyloric mucosa. A combination of pyloric metaplasia and small intestinal metaplasia was present in 11 patients.

In 12 cases multiple biopsies from the body were taken at the same time and in three patients repeat samples were taken at periods ranging from a few months to three years. The histological changes seen showed minimal variation from one area of the gastric body to another, both in the multiple biopsies and in repeat samples.

Endocrine cells were noticeably increased in eight cases. In the body the hyperplasia was usually associated with pyloric metaplasia. The hyperplasia was marked, almost to the point of completely replacing some of the pyloric glands in three cases (Figs. 7, 8). The endocrine cell proliferation was not

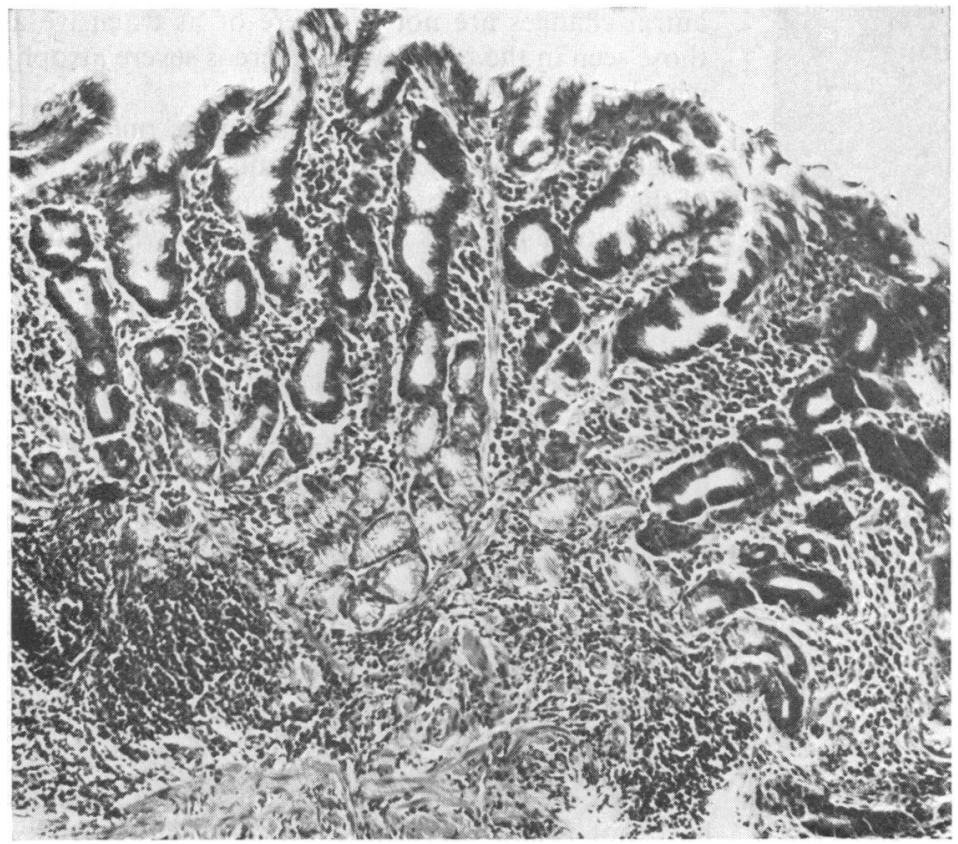

Fig. 4 Gastric mucosa from pyloric antrum in chronic gastritis, showing severe chronic inflammation and atrophy of coiled mucous glands. $\boldsymbol{H}$ and $E, \times 80$. 


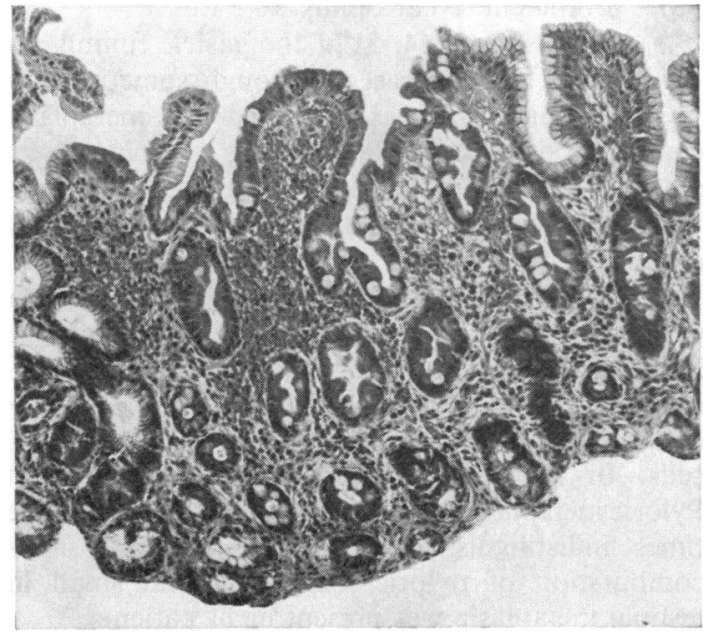

Fig. 5 Gastric mucosa from body in atrophic gastritis, showing intestinal metaplasia with goblet cells and columnar absorptive cells. $H$ and $E, \times 80$.

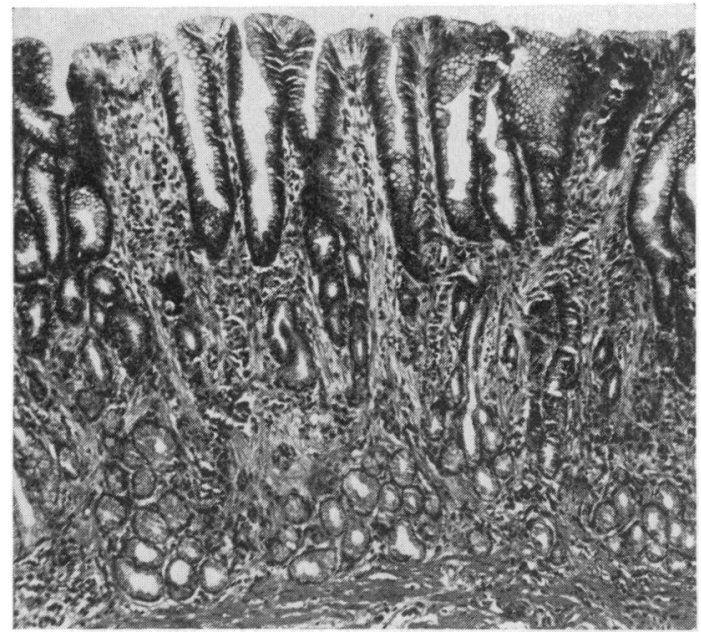

Fig. 6 Gastric mucosa from body in chronic atrophic gastritis showing severe pyloric metaplasia. Note resemblance of the mucosa to normal pyloric antrum. $H$ and $E, \times 80$.

consistently related to elevated gastrin levels. Of the eight cases with endocrine cell hyperplasia two had normal gastrin levels. Also of the 12 patients studied, eight had raised gastrin levels without showing any increase in endocrine cells.

\section{Discussion}

Before the introduction of peroral biopsy, the original observation by Magnus and Ungley (1938) drew attention to the histological distinction between body and antrum in PA. In chronic atrophic gastritis not associated with the lesion of PA this distinction has not been made. Peroral gastric biopsies from patients with chronic gastritis suggested that atrophic gastritis can be associated with inflammation of equal severity in the pyloric antrum, and that severe antral changes can occur with mild superficial gastritis or without disease of the body (Seifert and Knoll, 1968; Konturek and Urban, 1969; Ottenjann et al., 1969a). The interpretation of these findings is difficult, as the types of chronic gastritis studied by these authors were not clearly defined.

Strickland et al. (1971) found that their cases fell into two categories on the basis of the presence or absence of PCA and that those in which the antibodies were present showed in general sparing of the pyloric antral mucosa.

Our results are at variance with those of Magnus and Ungley (1938) and Strickland et al. (1971) and tend to support those of Seifert and Knoll (1968), Ottenjann et al. (1969b) and Konturek and Urban (1969). They indicate that the changes in chronic gastritis with PA almost always involve the entire gastric mucosa, including that of the pyloric antrum. Thus, in 16 patients with PA, varying in age between 29 and 74 years, only two appeared to have an unequivocally normal pyloric antral mucosa. The usual changes consist of alteration in mucosal thickness, glandular atrophy, metaplasia, and inflammatory changes of varying degree. However, the pyloric antral changes are not as severe or as extensive as those seen in the body, where there is severe atrophy with loss of the specialized cells.

From our material it is clear that one biopsy usually reflects the state of the mucosa of the body of the stomach as a whole. Thus, of 12 patients who had multiple biopsies and four patients who had repeat biopsies, only one had more than a $1+$ difference in inflammation from one biopsy to another, and in only one other was there significant difference in glandular atrophy. Similar findings were reported by Joske et al. (1955), Williams et al. (1958), Kirkpatrick et al. (1969). Exceptions to this are said to occur in antral gastritis and the rare cases of multifocal gastritis. In antral gastritis severe inflammation of the pyloric antrum can occur in the presence of a normal gastric body (Magnus and Ungley, 1938), and a biopsy of the body would not reflect these changes.

Conventionally, the morphological changes in severe chronic gastritis are divided into atrophic gastritis and gastric atrophy (te Velde et al., 1966; Konturek and Urban, 1969). In our experience the observed changes represent a continuum, and we have not found the distinction useful. Specifically, 


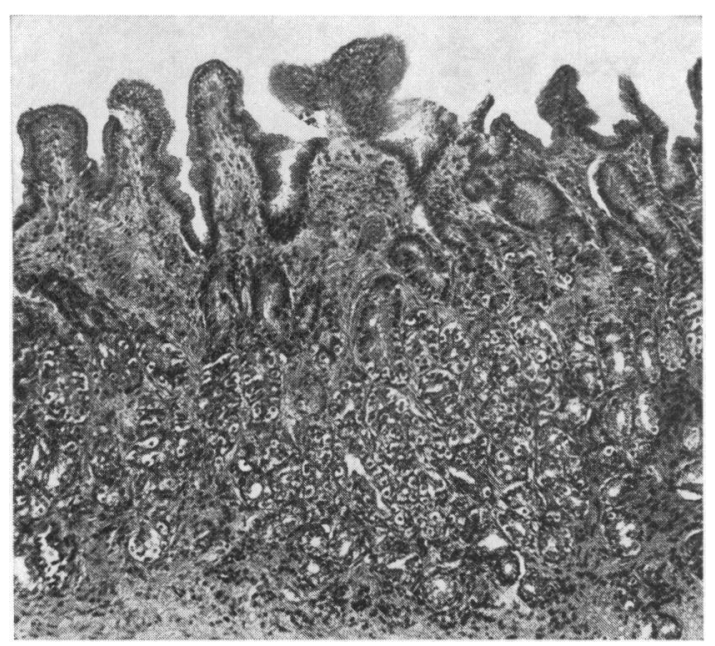

Fig. 7 Pyloric antrum in PA showing endocrine cell hyperplasia, almost to the point of completely replacing mucous cell of the pyloric glands. $H$ and $E, \times 80$.

we have never seen atrophy of the mucosa without a significant inflitrate in the lamina propria.

Occasionally gastric glands from the body in PA contained parietal cells. Some authors have reported residual parietal cells in up to $32 \%$ of their cases (Williams et al., 1958), and similar findings were noted by Markson and Davidson (1956), and Shiner and Doniach (1957). Whether these cells are functional or not is unclear, but they persist in the face of histamine-fast achlorhydria.

Our findings clearly show that metaplastic changes occur frequently in the gastric body. In the body these changes are severe and are composed of small intestinal metaplasia and pyloric metaplasia occurring singly or together. The occurrence of intestinal metaplasia is widely recognized and has been frequently stressed (Shiner and Doniach, 1957; Suirala, 1956; Morson, 1955; Rubin, 1969; Whitehead et al., 1972; Mitschke and Becker, 1973).

We wish to stress the frequency of pyloric metaplasia since, although recognized (Morson, 1955; Siurala, 1956; Shiner and Doniach, 1957; Rubin, 1969; Whitehead et al., 1972; Mitschke and Becker, 1973), it is not sufficiently emphasized throughout the literature. Furthermore, the severity of metaplasia can be such as to make the distinction between body and antrum on biopsy impossible, as severe gastritis with pyloric metaplasia, such as may be found in PA, may be misinterpreted as antral gastritis. Therefore, many of the previous studies based on material obtained by blind biopsy may be significantly misleading because the precise location of biopsy site is not always as clear-cut as under direct vision.

We did not observe a number of features described in chronic gastritis by others-namely, degenerative and regenerative changes of the superficial mucosa (Whitehead et al., 1972) and fibrosis of the lamina propria (Lambert, 1972).

In many of our cases of PA endocrine cells have been prominent, and, in three, florid proliferations of these cells almost replaced entire gastric glands in the body and pylorus. Although the endocrine cells were probably ' $G$ ' cells because of their location in the stomach, we could not be certain of this as immunocytochemical identification of gastrin was not attempted. Similar increases in numbers of endocrine cells of the stomach in PA with hyperplasia of the ' $G$ ' cells have been noted by others (Rubin, 1969; Creutzfeldt et al., 1971; Polak et al., 1973). In chronic atrophic gastritis with antral disease

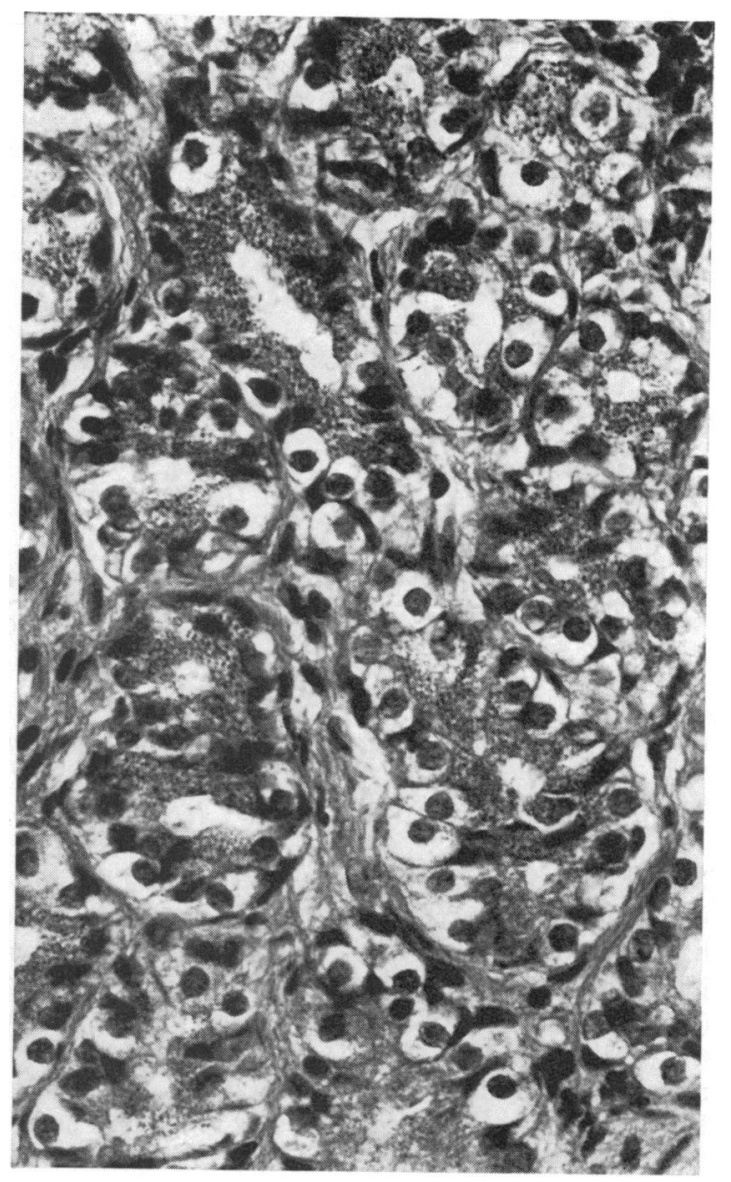

Fig. 8 Higher magnification of Fig. 7 showing endocrine cells with their characteristic central nuclei and perinuclear halos. $H$ and $E, \times 320$. 


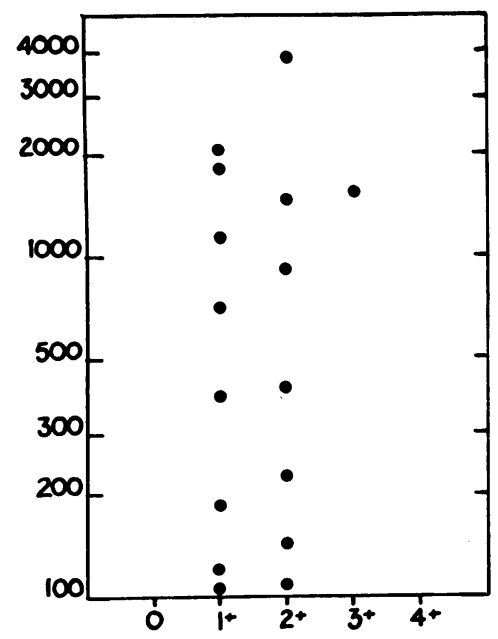

Fig. 92

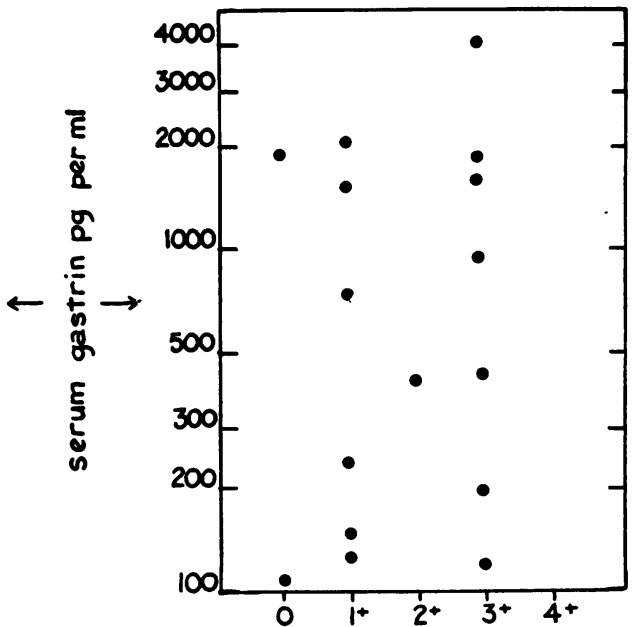

Fig. 9b

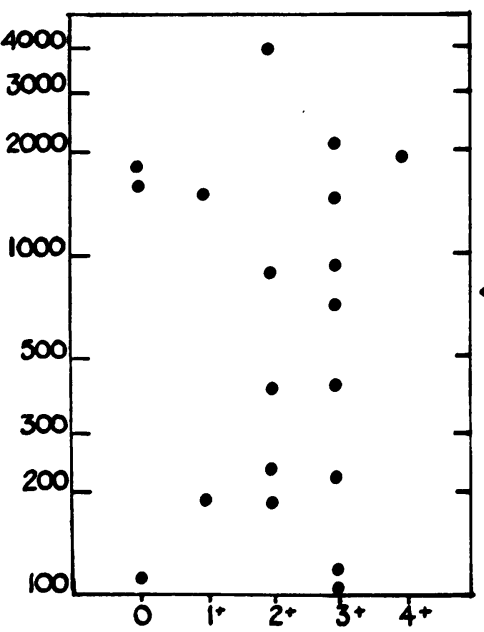

Fig. 90

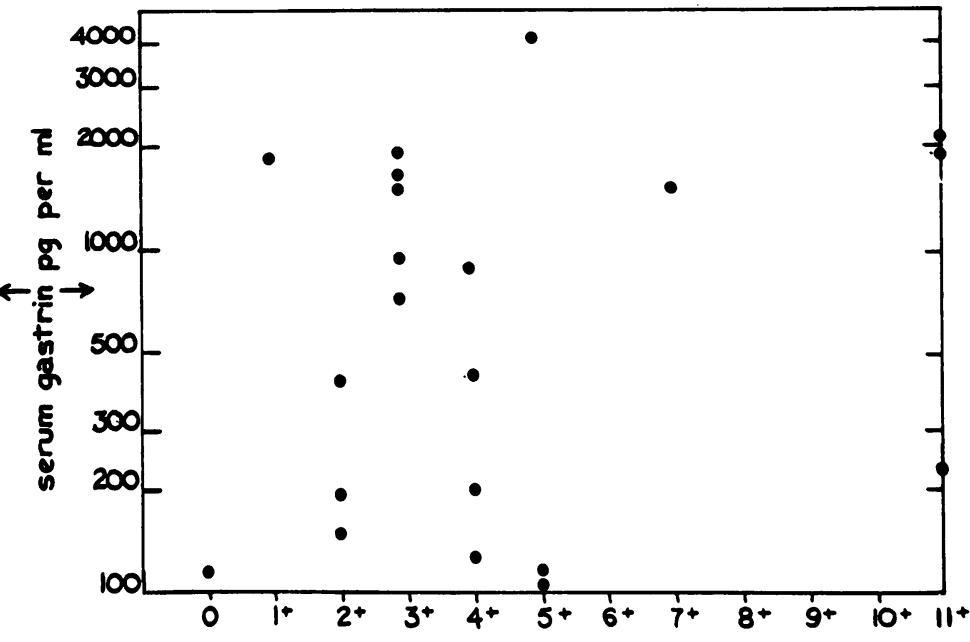

Fig. 9d

Fig. 9 Relation of serum gastrin level to (a) antral inflammation (b) antral atrophy, and (c) pyloric metaplasia of the body. (d) Serum gastrin levels plotted against pyloric and intestinal metaplasia and endocrine cell hyperplasia in the body scored cumulatively.

Mitschke and Becker( 1973) have reported a decrease in number of gastrin-containing ' $G$ ' cells, but we have been unable to confirm this. Gastrin has been identified by immunofluorescence in the ' $G$ ' cells (McGuigan, 1968; Ketterer et al., 1971), and in PA the proliferation of ' $G$ ' cells may be associated with raised serum gastrin levels (Creutzfeldt et al., 1971; Ketterer et al., 1971; Polak et al., 1973) and correlated with an increased gastrin concentration of the mucosa (Creutzfeldt et al., 1971). In simple atrophic gastritis gastrin levels are usually normal (Korman et al., 1971 ; Strickland et al., 1971). Our findings con- firm the raised gastrin levels in some cases of PA but we have found that ' $G$ ' cell hyperplasia is not always correlated with an elevation of serum gastrin. We have considered the following possible explanations for this: (1) the biopsy may not be representative of the status of endocrine cells; (2) gastrin synthesis may not be restricted to 'G' cells. Rubin (1973) has found that endocrine cells in nonintestinalized epithelium of the body in PA have the ultrastructure of enterochromaffin-like cells (ECL), and, furthermore, gastrin has been identified in many of these proliferated cells by immunofluorescence (Rubin, 
1973). We have noted this in one of our cases where ultrastructural studies were done. ' $G$ ' cell hyperplasia may not always be confined to the antrum, but may also occur in the body in pyloric metaplasia. We have therefore compared fasting serum gastrin levels with the degree of pyloric (Fig. 9c) and intestinal metaplasia in the gastric body together with endocrine cellular hyperplasia scored cumulatively (Fig. 9d). However no correlation emerges.

Strickland et al. (1971) have found that circulating gastrin levels in patients with achlorhydria can be related to the presence or absence of antral mucosal change. Their cases have fallen into two groups: (1) chronic atrophic gastritis associated with normal antrum, hypergastrinaemia and parietal cell antibodies; and (2) chronic atrophic gastritis with antral gastritis, normal serum gastrin, and no parietal cell antibodies. In the present study most of our patients with PA had antral gastritis of variable severity. No relationship between serum gastrin activity and the histological appearances of the antrum is apparent, which supports the concept of multiple gastrin sources (Figs. 9a and 9b). However, it is possible that these discrepancies are due to population differences or the relatively small size of the samples studied.

The authors are grateful to Stella Lindberg for technical assistance and Philip Horne for the photography.

\section{References}

Ashworth, L. A. E., England, J. M., Fisher, J. M., and Taylor, K. B. (1967). A new method for detection and measurement for intrinsic-factor antibodies. Lancet, 2 , 1160-1164.

Bock, O. A. A., Richards, W. C. D., and Witts, L. J. (1963). The relationship between acid secretion after augmented histamine stimulation and the histology of the gastric mucosa. Gut, 4, 112-114.

Creutzfeldt, W., Arnold, R., Creutzfeldt, C., Fewle, G., and Ketterer, H. (1971). Gastrin and G-cells in the antral mucosa of patients with pernicious anemia, acromegaly and hyperparathyroidism and in a Zollinger-Ellison tumour of the pancreas. Exropean Journal of Clinical Investigation, 1, 461-479.

Fisher, J. M., McKay, I. R., Taylor, K. B., and Ungar, B. (1967). An immunological study of categories of gastritis. Lancet, 1, 176-180.

Hoedemaker, P. J., and Ito, S. (1970). Ultrastructural localization of gastric parietal cell antigen with peroxidasecoupled antibody. Laboratory Investigation, 22, 184-188.

Hunter, W. M., and Greenwood, F. C. (1962). Preparation of iodine-131 labelled human growth hormone of high specific activity. Nature, 194, 495-496.

Joske, R. A., Finckh, E. S., and Wood, I. J. (1955). Gastric biopsy: study of 1000 consecutive successful biopsies. Quarterly Journal of Medicine, 24, 269-294.

Ketterer, H., Arnold, R., Creutzfeldt, C., Feurle, G., and Creutzfeldt, W. 1971). Gastrin Content, Immunohisto- logical and Ultrastructural Findings in the Antral Mucosa of Patients with Different Diseases. Edited by Ludwig Demling. Gastrointestinal Hormones International Symposium at Erlangen.

Kirkpatrick, J. R., Davis, G. T., Jacobs, A., and Williams, S. W. (1969). The recognition of atrophic gastritis. British Journal of Surgery, 56, 742-746.

Konturek, S. J., and Urban, A. (1969). The correlation between gastric acid secretion and histology of fundic and antral gland area. Scandinavian Journal of Gastroenterology, 4, 463-468.

Korman, M. G., Strickland, R. G., and Hansky, J. (1971). Serum gastrin in chronic gastritis. British Medical Journal, 2, 16-18.

Lambert, R. (1972). Chronic gastritis. Digestion, 7, 83-126.

McGuigan, J. E. (1968). Gastric mucosal intracellualr localization of gastrin by immunofluorescence. Gastroenterology, 55, 315-327.

Magnus, H. A., and Ungley, C. C. (1938). The gastric lesion in pernicious anaemia. Lancet, 1, 420-421.

Markson, J. L., and Davidson, W. M. B. (1956). Gastric biopsy in the megaloblastic anemias. Scottish Medical Journal, 1, 259-266.

Mitschke, H., and Becker, M. (1973). Zur Cytopathologie der disseminierten endokrinen Zellen des Magens bei Gastritis, Ulcus and Magencarcinom. Virchows Archiv fur Pathologische Anatomie und Physiologie, 358, 81-98.

Morson, B. C. (1955). Intestinal metaplasia of the gastric mucosa. British Journal of Cancer, 9, 365-376.

Ottenjann, R., Miederer, S., Elster, K., Stadelmann, O., and Rettenmaier, G. (1969a). Zangenbiopsie aus dem Antrum-, Korpus- und Kardiabereich des Magens unter endoskopischer Kontrolle. Klinische Wochenschrift, 47, 859-861.

Ottenjann, R., Paul, F., Dayhle, P., and Elsten, K. (1969b). Gastritis of the pyloric gland area and gastric acid secretion. Digestion, 2, 317-322.

Polak, J. M., Hoff brand, A. V., Reed, P. I., Bloom, S., and Pearse, A. G. E. (1973). Qualitative and quantitative studies of antral and fundic $G$ cells in pernicious anaemia. Scandinavian Journal of Gastroenterology, 8, 361-367.

Rosenquist, G. L., and Holmquist, A. M. (1974). Specificity of antibodies directed to porcine gastrin. Immunochemistry, 2, 489-494.

Rubin, W. (1969). Proliferation of endocrine-like (enterochromaffin) cells in atrophic gastric mucosa. Gastroenterology, 57, 641-648.

Rubin, W. (1973). A fine structural characterization of the proliferated endocrine cells in atrophic gastric mucosa. American Journal of Pathology, 70, 109-118.

Seifert, E., and Knoll, H. (1968). Bioptische Ergebnisse bei gleichzeitiger Entnahme von Fundus-und Antrumschleimhaut des Magens. Medizinische Welt, 1, 1219-1222.

Shiner, M., and Doniach, I. (1957). A study of X-ray negative dyspepsia with reference to histologic changes in gastric the mucosa. Gastroenterology, 32, 313-324.

Siurala, M. (1956). Pathology of atrophic gastritis. Annales Medicinae Internae Fenniae, 45, 67-90.

Strickland, R. G., Bhathal, P. S., Korman, M. G., and Hansky, J. (1971). Serum gastrin and the antral mucosa in atrophic gastritis. British Medical Journal, 4, 451-453.

Taylor, K. B., Roitt, I. M., Doniach, D., Couchman, K. G., and Shapland, C. (1962). Autoimmune phenomena in pernicious anaemia: gastric antibodies. British Medical Journal, 2, 1347-1352.

te Velde, K., Hoedemaker, P. J., Anders, G. J. P. A., Arends, A., and Nieweg, H. O. (1966). A comparative morphological and functional study of gastritis with and without autoantibodies. Gastroenterology, 51, 138-148.

Whitehead, R., Truelove, S. C., and Gear, M. W. L. (1972). 
The histological diagnosis of chronic gastritis in fibreoptic gastroscope biopsy specimens. Journal of Clinical Pathology, 25, 1-11

Williams, A. W., Coghill, N. F., and Edwards, F. (1958). The gastric mucosa in pernicious anaemia: biopsy studies. British Journal of Haematology, 4, 457-464.

Wood, I. J., Doig, R. K., Motteram, R., and Hughes, A. (1949). Gastric biopsy. Lancet, 1, 18-21.
Yalow, R. S., and Berson, S. A. (1970). Size and charge distinctions between endogenous human plasma gastrin in peripheral blood and heptadecapeptide gastrins. Gastroenterology, 58, 609-615.

Yip, B. S. S. C., and Jordan, P. H. (1970). Radioimmunoassay of gastrin using antiserum to porcine gastrin. Proceedings of the Society of the Experimental Biology and Medicine, 134, 380-385.

\section{The June 1976 Issue}

\section{THE JUNE 1976 ISSUE CONTAINS THE FOLLOWING PAPERS}

Lithocholate metabolism during chenotherapy for gallstone dissolution. 1. Serum levels of sulphated and unsulphated lithocholates R. N. ALLAN, J. L. THISTLE, A. F. HOFMANN, J. A. CARTER, AND P. Y. S. YU

Lithocholate metabolism during chenotherapy for gallstone dissolution. 2. Absorption and sulphation R. N. ALLAN, J. L. THISTLE, AND A. F. HOFMANN

Evidence for the absorption of bile acids in the proximal small intestine of normo- and hyperlipidaemic subjects B. ANGELIN, K. EINARSSON, AND K. HELLSTRÖM

Plasma oestrogens in men with chronic liver disease J. R. B. GREEN, N. A. G. MOWAT, R. A. FISHER, AND D. C. ANDERSON

Use of caerulein with submaximal doses of secretin as a test of pancreatic function in man A. RIBET, R. TOURNUT, M. DUFFAUT, AND N. VAYSSE

Effect of intraduodenal magnesium sulphate on pancreas and gallbladder of man J. H. B. SAUNDERS, B. THJODLEIFSSON, AND K. G. WORMSLEY

Radiographic evaluation of pancreatico-jejunal shunts E. W. MILLER, H. I. GOLDBERG, S. B. GOLDBERG, AND H. SHAPIRO
Electrogenic glucose absorption in untreated and treated coeliac disease N. W. READ, R. J. LEVIN, AND C. D. HOLDSWORTH

Factors affecting the absorption of vitamin $\mathrm{K}-1$ in vitro D. HOLLANDER AND ELENA RIM

Relation between body weight and the gastric and intestinal handling of an oral caloric load c. JOHANSSON AND K. EKELUND

Gastric mucosa after partial gastrectomy B. M. PULIMOOD, A. KNUDSEN, AND N. F. COGHILL

Highly selective vagotomy plus dilatation of the stenosis compared with truncal vagotomy and drainage in the treatment of pyloric stenosis secondary to duodenal ulceration M. J. MCMAHON, M. J. GREENALL, D. JOHNSTON, AND J. C. GOLIGHER

Proctocolitis and Crohn's disease of the colon: a comparison of the clinical course J. E. LENNARDJONES, JEAN K. RITCHIE, AND W. J. ZOHRAB

Fibrin thrombi, a cause of clindamycin-associated colitis? W. v. BOGOMOLETZ

Notes and activities

Notes on books

Copies are still available and may be obtained from the PUBLISHING MANAGER, BRITISH MEDICAL ASSOCIATION, TAVISTOCK SQUARE, LONDON, WC1H 9JR, price $£ 2.00$, including postage 